\title{
Improving the management of sustainable development of municipalities in the Kaliningrad region
}

\author{
Andrey Gorokhov ${ }^{1, *}$, Alexey Ignatyev ${ }^{2}$, Vitaly Smirnov ${ }^{3}$ and Grigory Yazev ${ }^{1}$ \\ ${ }^{1}$ Moscow state University of technology and management. K.G. Razumovsky, Zemlyanoy Val street, \\ 73, 109004, Moscow, Russia \\ ${ }^{2}$ The non-profit organization "Regional Economic Development Agency", Dmitry Donskoy street 1, \\ 236007, Kaliningrad, Russia \\ ${ }^{3}$ Moscow Aviation Institute, Volokolamskoe highway, 4, 125993, Moscow, Russia
}

\begin{abstract}
The paper describes the study of the process of managing the development of municipalities in the Kaliningrad region that were conducted by the Ministry for Municipal Development and Internal Policy of the Kaliningrad region, the Association "Council of Municipalities of the Kaliningrad region", and the Regional Economic Development Agency of the Kaliningrad region, as well as proposals based on them to improve the process of local sustainable development of the municipalities of the region.
\end{abstract}

\section{Introduction}

In order to achieve sustainable development of the regions, it is necessary first to ensure the sustainable development of municipalities of this territory [1].

In order to achieve this goal in the Kaliningrad region, active work is being carried out aimed at monitoring and analyzing the situation associated with managing the processes of local sustainable development since 2011 [2].

The study conducted in 2011 by the Agency for Regional Economic Development in conjunction with the Ministry for Municipal Development of the Kaliningrad region showed that there was practically no system of integrated management of the processes of local sustainable development in municipalities.

The study conducted in 2014 by the Ministry for Municipal Development and Internal Policy of the Kaliningrad region, the Association "Council of Municipalities of the Kaliningrad region", and the Agency for Regional Economic Development noted improvements in a number of parameters, but the main problems remained the same and did not receive a comprehensive solution $[1,3]$.

The study conducted in 2018 confirmed the previous picture: improvements are local and not systemic; in most cases, there is retention of previous indicators; in some cases - their deterioration.

\footnotetext{
*Corresponding author: andgorokhov@gmail.com
} 


\section{Materials and Methods}

The difference of the study conducted in 2018 is that municipalities of the first level - urban and rural settlements - were removed from it. The territorial and administrative reform, which is now completed in the Kaliningrad region, implies the transformation of municipal districts into urban districts with the transfer of powers from settlements to the latter. Thus, the functional units of territorial development, and therefore, the only full-fledged subject of study, are municipalities of the second level - urban districts.

Studies conducted in 2011, 2014, and 2018 are methodologically unified. In all cases, a survey was conducted in the form of a questionnaire at the municipal level. Five problematic question pools were studied: the availability of strategic planning documents in this municipality, the performance of the development function in municipalities, the issues of supporting small business development, the marketing of districts, and the situation in the local labor market, including the situation with unemployment.

The heads of municipalities, chiefs and employees of the financial and economic departments, economic development departments, and committees for planning and development of the economy participated in the preparation of answers to the questionnaire [4]. It should be noted that if the study conducted in 2014 involved 18 municipal districts and urban districts, then the study conducted in 2018 covered all municipalities of the second level in the region in the amount of 22 units [5]. In other words, 100\% representativeness of the sample was provided. At the same time, as before, there was a low performing discipline on the part of some respondents.

Comparative results of surveys conducted in municipalities in 2014 and 2018 are reflected in Table 1.

Table 1. Integrated management of the development of municipalities in the Kaliningrad region.

\begin{tabular}{|c|c|c|c|c|}
\hline \multirow{2}{*}{ № } & & \multirow{2}{*}{ Name of questions } & \multicolumn{2}{|c|}{$\begin{array}{c}\text { Municipalities of the } \\
\text { second level }\end{array}$} \\
\hline & & & $\begin{array}{c}2014(18 \\
\text { munic.) }\end{array}$ & $\begin{array}{c}2018(22 \\
\text { munic.) }\end{array}$ \\
\hline \multirow[t]{3}{*}{1} & \multirow{3}{*}{$\begin{array}{l}\text { Availability of } \\
\text { strategic planning } \\
\text { documents }\end{array}$} & Development strategy & 15 & 14 \\
\hline & & Program / Plan of action & 16 & 10 \\
\hline & & $\begin{array}{l}\text { Labor body for managing the strategy } \\
\text { (program) }\end{array}$ & 11 & 13 \\
\hline \multirow[t]{3}{*}{2} & \multirow{3}{*}{$\begin{array}{l}\text { Performing the } \\
\text { function of } \\
\text { development }\end{array}$} & $\begin{array}{l}\text { Development powers are assigned to } \\
\text { functional units }\end{array}$ & 15 & 16 \\
\hline & & Investment passport & 9 & 14 \\
\hline & & Industrial and investment sites & 16 & 20 \\
\hline \multirow[t]{2}{*}{3} & \multirow{2}{*}{$\begin{array}{l}\text { Support of small } \\
\text { business }\end{array}$} & Small Business Support Centres (SBSC) & 9 & 10 \\
\hline & & $\begin{array}{l}\text { Statistical information on the activities of } \\
\text { small business }\end{array}$ & 10 & 10 \\
\hline \multirow[t]{2}{*}{4} & \multirow{2}{*}{$\begin{array}{l}\text { Carrying out of } \\
\text { marketing } \\
\text { researches }\end{array}$} & Availability of specialized professionals & 13 & 12 \\
\hline & & Promotion programs of municipalities & 1 & 2 \\
\hline 5 & $\begin{array}{l}\text { Labor resources, } \\
\text { situation with } \\
\text { unemployment }\end{array}$ & $\begin{array}{l}\text { Documents on the analysis, dynamics, and } \\
\text { condition of the able-bodied population }\end{array}$ & 16 & 19 \\
\hline
\end{tabular}




\subsection{The first question pool: strategic planning documents}

Based on the data of the table, it was established that in 2018, the strategic documents adopted for execution in the municipalities of the Kaliningrad region were less than in 2014. However, the situation is not so straightforward and requires a separate commentary. The fact is that the term of previous development strategies has expired in several municipalities at once, and new ones are under development - there are six of them today.

The wave of renewal affected many municipalities - most of current strategies and plans of action were developed in 2016-2018. At the same time, some municipalities consciously postpone the completion of the development. The goal is to synchronize the documents of strategic planning with two framework documents related to the development of the country (the May decree of the President of the Russian Federation) and the Kaliningrad region (Regional Development Strategy, which should be adopted later this year).

On the one hand, municipalities are gradually moving away from the practice of developing program documents solely by the administration personnel and are increasingly involving specialized experts (from organizations, such as the Immanuel Kant Baltic Federal University (Kant BFU), local branches of the Russian Academy of Agricultural Sciences and the Russian Union of Industrialists and Entrepreneurs, the Baltic Business Club etc.). So did in the nine municipalities. Further, some municipalities are aware of the need to involve representatives of the civil sector in the development and discussion of development strategies. In this respect, the strategy of the Gvardeysky urban district is indicative and can be accepted as a model for the entire region.

On the other hand, there is an opposite tendency. Only 10 municipalities out of 22 who took part in the survey conducted seminars with the participation of representative authorities, businesses, public organizations, and leaders of urban and rural settlements when developing strategic documents. There were 14 out of 18 in 2014.

According to other indicators, for example, the presence in the municipality of a labor body for managing the development strategy; the practice of holding public hearings on issues of socio-economic and territorial development, the situation has not fundamentally changed. In the first case, labor bodies are created primarily in the structure of administrations, which makes independent audit difficult. In the second case, the problems of public hearings are in the old, traditional canvas - the leadership of the municipalities involves the public mainly to discuss current budgets and master plans.

The overall dynamics of the indicators of 2018 relative to 2014 is nearly zero. Like four years ago, the process of developing and approving strategic planning documents in the overwhelming majority of municipalities has not been completed, and the process of strategic planning is not systemic.

\subsection{The second question pool: ensuring the development function in the municipality}

In 2018, the proportion of municipalities in which the development powers were assigned to the functional units of the administration was comparable to one that was observed four years earlier: 16 and 15, respectively. The inventory process of the available development resources has accelerated - today, 14 municipalities have investment passports, the presence of industrial and investment sites was confirmed by 20 municipalities.

There are two main problems associated with ensuring the strategic development of the territories.

The first problem. In the overwhelming majority of municipalities, "project offices" specialized management bodies responsible for implementing projects as a part of the 
development strategy - have not yet been created. The fact that functional units are created within administrations at the level of financial and economic departments testifies to a lack of understanding of the very logic of managing strategic development and the implementation of relevant projects. These projects also include, in addition to administrative, a "civil" part (for example, private-municipal partnership, participation in co-financing programs, cross-border cooperation programs, etc.). Therefore, representatives of the civil sector and the business community should be integrated into the project office. At the same time, the management of the municipality must directly supervise its work, bypassing the middle management, since it is necessary to separate the functions of the current process management of the municipality from the functions of strategic development.

The second problem is in the low quality of specialists who do not have the skills of project management. According to the survey, only 8 municipalities have employees who have completed trainings on using a project approach to planning and implementing project activities. Only 7 municipalities stated the presence of personnel responsible for the development function in administrations who speak foreign languages (on average, 1-2 people in this municipality).

Thus, the level of qualification of local personnel entrusted with the implementation of strategic development projects remains insufficient.

However, there is also a positive tendency. It is associated with an awareness of the limitations in development caused by this state of affairs. When asked whether there is a need for additional training of specialists, all municipalities without exception answered in the affirmative. The number of employees this municipality would like to send to the courses and trainings varies from 2 to 24 people.

\subsection{The third question pool: support of small business}

Based on the study conducted in 2014, it was ascertained that at least half of municipalities of the second level does not have a system analysis of the state and development of small business, and the level of support as a whole remains low and varies considerably in different regions. Since then, the situation has changed little (and it even became worse in percentage terms). Today, only 10 municipalities out of 22 have support centers for small business. Also, only 10 municipal administrations have statistical information on the activities of small businesses in the territory of this district. Moreover, there has been a decline in the number of enterprises supported by development and support programs of the municipal administration and the government of the Kaliningrad region.

However, there are also positive tendencies. In 2014, 10 municipalities ascertained an increase in the number of small businesses in the territory, and in 2018 - 15. Four years ago, 2 municipalities could not provide statistics because they did not monitor the activity of small businesses. Today, such monitoring is carried out in all municipalities. Finally, the number of municipalities that analyze the programs of state (municipal) support for small business has grown.

\subsection{The fourth question pool: marketing of municipalities}

The basic tool for promoting the municipality is the official website. It should contain information designed to meet the needs of key target audiences: local residents (including potential migrants), business community (including potential investors), and tourists.

In 2018, an information network of websites was created in all municipalities of the Kaliningrad region, except of the Neman district. In the overwhelming majority of the municipalities, information is updated daily, feedback is provided to citizens. The number of 
daily visits varies from several hundred to 15 thousand (urban district "City of Kaliningrad"). It can be stated that websites quite effectively solve the problem of informing citizens about the work of municipal authorities and socially significant budget institutions, as well as about the significant events for local communities in the cultural, sports and leisure sphere, etc.

At the same time, local Internet resources have not become a marketing tool for the promotion of municipalities and are not even recognized as such ones. According to the survey, the target audience of municipal sites is blurry understood by their creators: "unlimited number of users", "all interested". Or it narrows to citizens - consumers of social services already living on the territory of the municipality.

In rare cases, for example, in the answers of the respondents from the Gvardeysky and Guryevsky municipal districts, "potential investors" are mentioned. No one identifies potential migrants as a target group of marketing influence.

The promotion program is created only in two municipalities (Chernyakhovsky and Gvardeysky urban districts). The number of municipalities where individual specialists work in these areas has decreased from 13 to 12 .

In other words, even in those municipalities where strategic development documents have been developed, often there are no necessary marketing tools to put them into effect. The level of marketing in municipalities remains low and weakly focused on the end consumer. Municipalities do not have a strong brand reflecting its mission, features, and competitive advantages.

\subsection{The fifth question pool: labor resources, unemployment}

In 2014, there were no documents on the analysis of the dynamics and condition of the able-bodied population in two administrations of municipalities, and in other municipalities, such documents were available, but not in full. Four years later, the situation has changed little - the lack of labor market analytics was stated by 3 municipalities.

The growth of unemployment is now observed in one municipality (in 2014 - in 3). Positive dynamics to reduce unemployment was confirmed in 16 municipalities (in the previous period - in 14).

As before, the overwhelming majority of municipalities reported the lack of information on the number of residents working outside the municipality, as well as the number of residents of other municipalities working on this territory. This indicates that the analysis of labor resources by the municipal administrations is weak or not conducted at all.

Meanwhile, today, the commuting has sharply increased in the Kaliningrad region. Two typical cases: residents of the Kaliningrad periphery come to work in large cities of the region every day; residents of large cities, while retaining work there, move to live in the province. This creates an increasing tension between the increased budgetary burden of the municipality in terms of fulfilling social obligations to the growing population and the revenue base of the budget, which is growing at a much slower pace, since personal income tax is the main source of tax paid in other municipality. Availability of information on the situation on the labor market is critical for strategic planning, budgeting of municipal expenditures, development of small business, etc.

\subsection{How to improve the effectiveness of the development of municipalities: proposals of municipalities}

Proposals of municipalities of the Kaliningrad region can be combined into the following blocks: 
1. Improvement of the financial security of municipality; increase in the percentage of deductions;

2. Management of municipal finances, strengthening control over the implementation of taxes credited to the local budget;

3. Improvement of the quality of targeted programs;

4. More active involvement of the municipality in financing under the FTP and DIP programs, in the part of the implementation of national projects, international funds, etc.;

5. Encouragement of external investments, support of small business by the municipality;

6. Development of the system of interaction of regional authorities with local authorities;

7. Inventory of the resources of municipality and completion of development of strategies and programs for the development of these territories;

8. Continuation of the implementation of strategic planning and management, additional profile training of employees;

9. Creation in the municipal administrations of a profile structure (department) responsible for the development and promotion of the municipality;

10. Active involvement of the public in participation in the discussion of the activities of public authorities;

11. Use of mass media for the promotion of municipalities.

In comparison with the proposals that respondents put forward during the previous survey, three new significant trends emerged. This is a clearer recognition at the municipal level that:

1. To ensure the development function at the municipal level, specialized structures with their unique competence are required (project offices);

2. It is necessary to introduce modern management practices, which implies the training of competent specialists.

3. Strategic planning requires wide interaction of municipal authorities with civil society, as it becomes a powerful source of formation and mobilization of new resources for municipal development.

\section{Conclusion}

Based on the results of the questionnaire conducted in 2014, conclusions were drawn that remain relevant today: "During the period of completed studies $(2011,2014$, and 2018), there are tendencies to improve certain indicators, but significant changes in this area of municipal management in Kaliningrad region did not happen. It seems advisable to make a function of local sustainable development of the municipalities of the region systemic" [6].

The lack of an integrated approach to local sustainable development is a constant, which is recorded in municipalities of the Kaliningrad region throughout the seven-year period of study. One of the reasons is that the leadership of the majority of municipalities is still considering the development of strategic planning documents as a formally compulsory service that has no immediate significance for the development of the territories.

However, the reason is not only and not so much in this. Current territorial and administrative structure of the region is not well adapted to the implementation of project approaches within the unified strategies [7].

Firstly, 22 municipalities divide the territory of the region into small fragmented units that are fully capable of supporting social infrastructure, but do not have sufficient personnel, land, administrative, budgetary resources for integrated development. As one of the consequences - the functions of the current management of social infrastructure in municipalities are not separated from the functions of strategic planning and almost completely subordinate them. 
Secondly, the impulse for modernization of local management, which could be given by the regional government, is "drowned" by an excessive number of municipal actors. The Ministry for Municipal Development and Internal Policy of the Kaliningrad region itself sometimes "stumbles" in the tasks of the current process management of the numerous diverse municipalities in the region.

Thirdly, this fragmentation prevents the creation of full-fledged development strategies. On the one hand, they often conflict with each other. The images of the future of neighboring municipalities are poorly linked with each other and cannot be fully realized, since they require consolidated intermunicipal support, alignment of interests. A typical case is the urban district "City of Kaliningrad", which has almost exhausted the territorial and infrastructural resources of development, and critically depends on interaction with the surrounding municipalities.

It seems that all these problems can be solved by the creation of a system of several large agglomerations in the territory of the Kaliningrad region. For example, around such centers as Kaliningrad, Chernyakhovsk-Gusev, and Sovetsk.

The transfer of the functions of strategic planning and development to the agglomeration level will allow:

1. Developing the strategies and programs for the integrated development of territories, the uniformity and consistency of which will be combined with the specificity of the municipalities included in this agglomeration;

2. Providing the "project offices" of agglomerations with all the necessary resources financial, personnel, land, etc. due to economies of scale;

3. Dividing the functions of strategic development and current management of social infrastructure;

4. Carrying out effective interaction of the regional government with municipalities due to a sharp decrease in the number of counterparties, achieving consolidation of regional and municipal resources within a single municipal policy;

5. Providing reliable techniques for monitoring, supervision, and control for the mechanism proposed in the previous study of 2014. This involves building a system for increasing the responsibility of the municipal government in the part related to the executive discipline (punish for improper performance of instructions), and in the part related to the building of the (inter) municipal development system in general.

The implementation of the agglomeration principle in the Kaliningrad region will be the first such experience in the subjects of the Russian Federation. This will confirm the "pilot" role of the region, which he historically played in modern Russia. If it will be successful, the Kaliningrad management practices can be replicated to other parts of the country.

\section{References}

1. V.N. Ivanova, A.Y. Gorohov, A.Y. Ignatev, A.A. Ignateva, V.G. Smirnov, Ekonomicheskie nauki 4(125), 94-99 (2016)

2. Jones, G. Fallon, R. Golov, European Business Review 12(4), 187-197, doi. 10.1108/09555340010336871

3. I.V. Ilin, A.I. Levina, O.Yu. Iliashenko, MATEC Web of Conf. 86, 05028 (2016) doi: 10.1051/matecconf/20168605028

4. Ilin, O. Kalinina, O. Iliashenko, A. Levina, Procedia Engineering 165, 1673- 1682 (2016) doi: 10.1016/j.proeng.2016.11.909

5. Zaychenko, S. Gutman, O. Kalinina, Advances in Intelligent Systems and Computing 692, 453-462 (2018) doi: 10.1007/978-3-319-70987-1_48 
6. A.Y. Gorohov, D.A, Gorohov A.Y. Ignatev, V.G. Smirnov, Ekonomicheskie nauki 11, 64-72 (2016)

7. V. Vilken, O. Kalinina, A. Dubgorn, E3S Web of Conferences 33, 03012 (2018), doi:10.1051/e3sconf/20183303012 